\title{
Present and past bio-available phosphorus budget in the ultra- oligotrophic Lake Brienz
}

\section{Journal Article}

\section{Author(s):}

Müller, Beat; Finger, David; Sturm, Michael; Prasuhn, Volker; Haltmeier, Thomas; Bossard, Peter; Hoyle, Catherine; Wüest, Alfred

Publication date:

2007-06

Permanent link:

https://doi.org/10.3929/ethz-b-000066933

\section{Rights / license:}

In Copyright - Non-Commercial Use Permitted

\section{Originally published in:}

Aquatic Sciences 69(2), https://doi.org/10.1007/s00027-007-0871-8 


\title{
Research Article
}

\section{Present and past bio-available phosphorus budget in the ultra-oligotrophic Lake Brienz}

\author{
Beat Müller ${ }^{1, *}$, David Finger ${ }^{1,2}$, Michael Sturm ${ }^{1}$, Volker Prasuhn ${ }^{3}$, \\ Thomas Haltmeier ${ }^{4}$, Peter Bossard ${ }^{1}$, Catherine Hoyle ${ }^{1}$ and Alfred Wüiest ${ }^{1,2}$ \\ ${ }^{1}$ Swiss Federal Institute of Aquatic Science and Technology, Eawag, CH-6047 Kastanienbaum, Switzerland \\ ${ }^{2}$ Institute of Biogeochemistry and Pollutant Dynamics, ETH, CH-8092 Zürich, Switzerland \\ ${ }^{3}$ Swiss Federal Research Station for Agroecology and Agriculture, Agroscope FAL Reckenholz, \\ Reckenholzstr. 191, CH-8046 Zürich, Switzerland \\ ${ }^{4}$ Bonnard \& Gardel, Ingenieure und Berater AG, Lorystrasse 6a, CH-3000 Bern 5, Switzerland
}

Received: 28 March 2006; revised manuscript accepted: 30 January 2007

\begin{abstract}
A detailed budget of the fluxes of bioavailable phosphorus (bio-P) was established for the ultra-oligotrophic Lake Brienz (Switzerland) and its catchment. Lake Brienz is a cold, deep oligotrophic peri-alpine lake that receives an annual load of approximately $300 \mathrm{kt}$ of suspended sediments, mainly from two glacier-influenced rivers. The challenge was to overcome the associated high background of mineral-bound inorganic phosphorus (IP) of $\sim 200 \mathrm{t}$ $\mathrm{yr}^{-1}$ that is mostly inaccessible to algae growth. The application of six complementary, independent datasets allowed a consistent balance of bio-P to be obtained. We made use of data on (a) the load imported by the contributing rivers, (b) net sedimentation from cores, (c) export of bio-P from catchment land to the surface waters estimated by a GIS model, (d) the downward flux of bio-P through the water column from sediment traps, (e) primary production, and (f) the mineralization rate of organic material from the consumption of oxidants in the uppermost
\end{abstract}

sediment of the lake. The average bio-P load estimated from import measurements and net sedimentation is $7.0 \mathrm{t} \mathrm{yr}^{-1}$ with an error of about $10 \%$ : An estimated $5.4 \mathrm{t} \mathrm{yr}^{-1}$ enters by way of the two main rivers (including $0.9 \mathrm{t} \mathrm{yr}^{-1}$ from sewage treatment plants), $1.2 \mathrm{t} \mathrm{yr}^{-1}$ from the remaining catchment (including $0.4 \mathrm{t} \mathrm{yr}^{-1}$ from sewage treatment plants that are

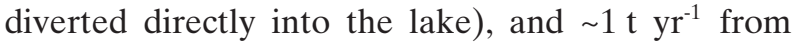
atmospheric deposition. Approximately $2 \mathrm{t}$ of bio-P are retained annually in the sediments of the upstream dams and thereby withheld from downstream Lake Brienz. The maximum eutrophication of the lake in the late 1970s and the subsequent re-oligotrophication can be attributed to the loads of urban wastewater. The drop in biological productivity since the late 1970s is consistent with the decrease of bio-P fluxes archived in the sediment, the record of the sewage treatment plant outflows and the few occasional in-situ observations.

Key words. Phosphate balance; particles; re-oligotrophication; pore-water; ion-selective electrodes.

\footnotetext{
* Corresponding author phone: +41413492149 ;

e-mail: beat.mueller@eawag.ch

Published Online First: June 6, 2007
} 


\section{Introduction}

A significant decrease of fish catch and a claimed increase of turbidity in Lake Brienz, which is an ultraoligotrophic peri-alpine, deep cold-water lake in Switzerland, have lead to much speculation regarding the potential causes. In this paper we focus on the estimation of the fluxes of bio-available phosphate (bio-P), which is readily available for uptake by algae and is the limiting nutrient for productivity in Lake Brienz. This is a challenging task, as the inorganic background phosphorus fluxes are many times larger than bio-P and the anthropogenic influences are significant. For instance, hydropower production has greatly altered the particle loads to Lake Brienz since the 1930s (Wüest et al., 2007). In former times, approximately $500 \mathrm{kt}$ of erosion material $\left(1 \mathrm{kt}=10^{3}\right.$ metric tons) in the form of suspended particulate matter (Anselmetti et al., 2007) and colloids (Chanudet and Filella, 2007) were transported to the lake annually. Due to storage in the upstream reservoirs, the loads of water and particles have decreased in summer and been shifted to winter and springtime periods (Finger et al., 2006). Hence, the phosphorus (P) loading and, in particular, the potentially bioavailable phosphate associated with the particles has also been shifted temporally. Moreover, about $230 \mathrm{kt}$ $\mathrm{yr}^{-1}$ of erosion matter is permanently deposited in the upstream reservoirs at present.

During the last century, anthropogenic $\mathrm{P}$ inputs to Lake Brienz first increased due to the construction of sewer systems that directed domestic effluent waste into the lake, and then decreased after the 1980s due to the operation of sewage treatment plants (STP) with iron-induced $\mathrm{P}$ precipitation (Wüest et al., 2007).

The optimization of STPs, the prohibition of Pcontaining detergents, and the retention of potentially bio-P in the upstream reservoirs are assumed to be the main causes of the return to the lake's present oligotrophic or near-natural low-nutrient condition. However, the effects of the seasonal shift of particle and bio-P loads, the altered light regime in the lake (Jaun et al., 2007), as well as the subsequent effects on primary productivity (Finger et al., 2007) and, thus, on the entire food chain of the lake (Rellstab et al., 2007; Müller et al., 2007b) have caused much public debate. Our goal is, therefore, to generate a detailed budget for bio-P of the lake, which includes the high particle loads and the dissolved inorganic P (DIP) concentrations at or below the detection limit of conventional analytical methods demanding a profound knowledge of chemical speciation and characterization of the interactions with the particle surfaces.

\section{Forms of phosphorus in Lake Brienz}

The weathering rocks of the upstream alpine catchment contain approximately $660 \mathrm{ppm}$ of inorganic

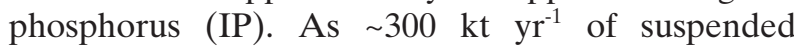
particles reach the lake, more than $200 \mathrm{t} \mathrm{yr}^{-1}$ of IP plus some additional dissolved and particulate organic forms are flushed into Lake Brienz (Wüest et al., unpubl. data). Most of the inorganic mineral form of $\mathrm{P}$ (apatite) remains largely unavailable to the biota due to low solubility products and slow dissolution, whereas the rest is likely present as rather refractory particulate organic remains of soil, wood debris, leaf litter, etc. that settle quickly and mineralize slowly. Organic particles from soil erosion were ineffective for eutrophication (Moosmann et al., 2006), whereas $\mathrm{P}$ bound in bacterial biomass from STPs as well as P assimilated in algae were assumed to be available only after mineralization in the water column or during the process of early diagenesis in the sediments (Hupfer et al., 1995). Few forms of $\mathrm{P}$ are, therefore, available to algae growth in the photic zone. Only the freely dissolved ions $\mathrm{H}_{2} \mathrm{PO}_{4}^{-}$and $\mathrm{HPO}_{4}{ }^{2-}$ are readily assimilated, whereas as indicated above dissolved organically bound $\mathrm{P}$ (DOP) requires degradation before new biological uptake is possible.

The IP associated with colloids that pass through a $0.45 \mu \mathrm{m}$ filter membrane cannot be separated from dissolved $\mathrm{P}$ and is thus included in the bio-P fraction (Sinaj et al., 1998). DIP binds strongly to iron (Fe) oxide surfaces but can be released back into solution when Fe particles are reductively dissolved. Reversible sorption of $\mathrm{P}$ to aquatic particles of crystalline origin is commonly neglected, since interactions are small and thus difficult to quantify. However, this process becomes increasingly important for high concentrations of suspended particles and small $\mathrm{P}$ concentrations (Ioannou and Dimirkou, 1997). The chemical characterization of $\mathrm{P}$ species occurring in natural waters is challenging and depends on the methods applied. Whereas sequential extraction procedures overestimate releasable $\mathrm{P}$ due to the harsh chemical treatment (Ruban et al., 2001), the characterization of bio-P by passive desorption (Müller et al., 2006a) corresponds more closely to the natural processes of suspension and transport as well as the concentration and dilution of particles.

As bio-P is only a small fraction of the total mainly particulate - TP and particle loads are very high, the interaction between dissolved $\mathrm{P}$ and particle surfaces must be considered.

In order to understand the low biological productivity of this particle-laden lake, we need a careful estimation of the small fraction of bio-P distributed in various chemical forms in the presence of the high flux of total P. These characterizations may help estimate 


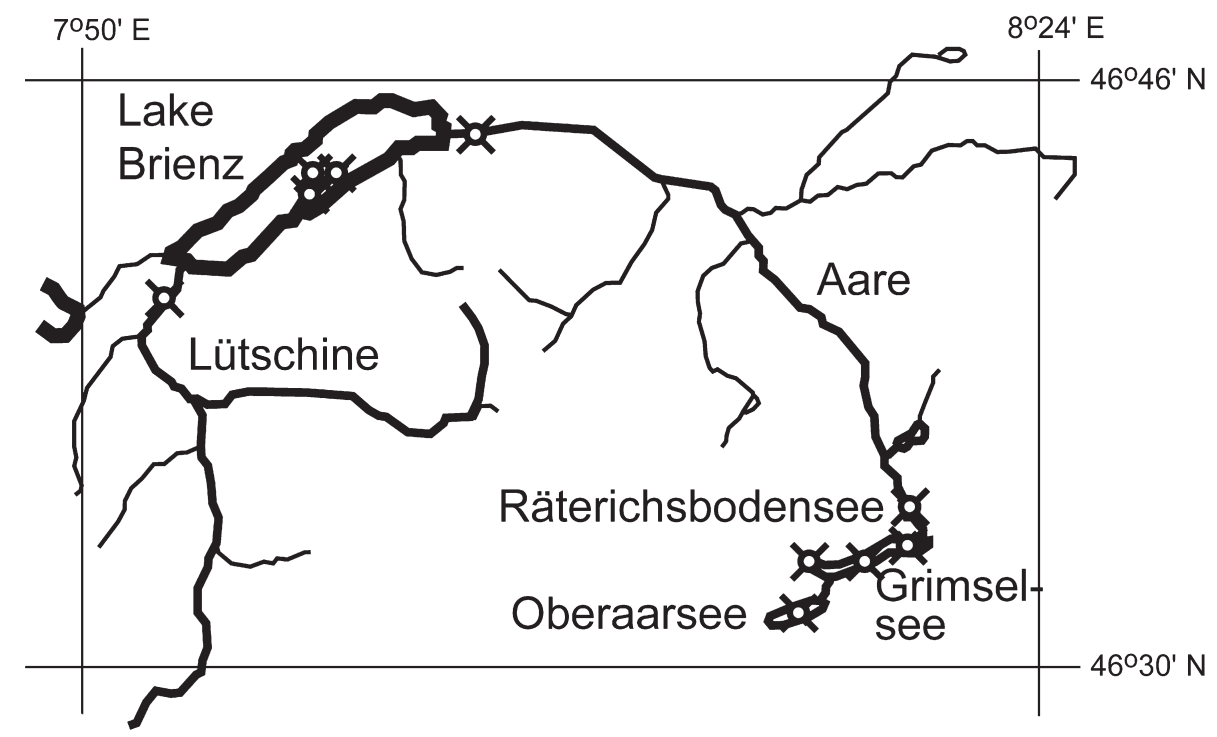

Figure 1. Map of Lake Brienz and its catchment with the main tributaries Aare and Lütschine. Hydropower reservoirs are located in the headwaters of the Aare. Crosses mark the sampling sites.

the loads of bio-P entering the lake from its catchment as well as help determine the scavenging of potential bio-P by deposition in the hydropower reservoirs. In order to verify the estimated $\mathrm{P}$ available for primary production and to establish a detailed $\mathrm{P}$ budget for Lake Brienz and its catchment, we will compare and assess in this paper the following six independent data sets: (1) Bio-P entering the lake by the rivers Aare and Lütschine either dissolved or sorbed to suspended particles and estimation of the intrusion depths of the river inflows; (2) bio-P leaving the lake by way of net sedimentation from sediment cores and by the outflow; (3) an estimate of the transfer of dissolved P from land to surface waters using a catchment-based geographical information system model; (4) the flux of settling particles from sediment trap measurements (net system production); (5) the consumption of oxygen $\left(\mathrm{O}_{2}\right)$, nitrate $\left(\mathrm{NO}_{3}{ }^{-}\right)$and sulfate $\left(\mathrm{SO}_{4}{ }^{2-}\right)$ in the sediments (mineralization) determined with microoptodes and porewater measurements; and (6) measurements of primary productivity (Finger et al., 2007).

\section{Methods}

\section{Sites and sampling}

The geographical setting and characteristics of Lake Brienz, its catchment and its tributaries are described in detail by Wüest et al. (2007). The sedimentation and deposition of particles in Lake Brienz is very inhomogeneous. Irregular sedimentation might be caused by lake morphology, flood events, slumps and the formation of delta zones (Anselmetti et al., 2007).
Therefore, we selected coring sites on a side plain (Fig. 1) elevated by $\sim 40 \mathrm{~m}$ above the deepest reaches, where sediment deposition was found to be undisturbed for the last nine years. Four sediment cores from 20 and $212 \mathrm{~m}$ depth, as well as 23 and $210 \mathrm{~m}$ depth (site A: 20/23 m depth at position 640895/ 173967 (Swiss Grid); site B: 210/212 m depth at position 641150/174850) were collected on 6 May and 30 November 2004, respectively, and analyzed. Sediment trap material from a mooring in the center of the lake was collected between March 2003 and November 2004 at intervals of up to two months and was afterwards used for $\mathrm{P}$ speciation experiments. The sediment traps did not contain the large allochthonous particles transported by the rivers, which settled at the delta. Deposits in the three upstream reservoirs Grimselsee, Räterichsbodensee, and Oberaarsee were grab-sampled in October 2002. Suspended particles from Aare and Lütschine were obtained by filtration $(0.45 \mu \mathrm{m}$ membrane filters) of water samples collected during floodwater (details in Müller et al., 2006a). Cores from 6 May 2004 were dated with the ${ }^{137}$ Cs method (Wan et al., 1987).

\section{Sequential extraction}

We applied an analytical protocol for the determination of extractable $\mathrm{P}$ fractions from freshwater sediments developed by Ruban et al. (1999; 2001) according to the Standards Measurements and Testing Program of the European Commission (Wüest et al., in prep.). Sequential extractions using standard reference sediment (IRMM, 2001) were repeated eight times to verify the reproducibility. Mean values 
differed from certified values by $\leq 4 \%$ for $\mathrm{NaOH}-\mathrm{P}$ (non-apatitic, inorganic, iron-bound $\mathrm{P}$ that is potentially bio-available), IP, and TP, and by $20 \%$ for $\mathrm{HCl}-\mathrm{P}$ (Ca-bound, apatitic $\mathrm{P}$ which is non-bio-available) and organic P (OP). Standard deviations were similar to those of certified measurements.

\section{Passive desorption}

The determination of $\mathrm{P}$ sorption parameters by applying passive desorption is given in Müller et al. (2006a). In brief, two types of experiments were performed in order to cover $\mathrm{P}$ sorption under both situations, low and high surface coverage. In experiments with low surface coverage (desorption), a particle stock suspension was diluted in $1 \mathrm{mM}$ $\mathrm{HCO}_{3}^{-}$(resulting $\mathrm{pH}$ 8.6) without addition of phosphate. This caused mere desorption of inorganic and organic $\mathrm{P}$. The sorption parameters are depicted as $\mathrm{K}_{\mathrm{DIP}}, \mathrm{K}_{\mathrm{DOB}}, \mathrm{K}_{\mathrm{TDP}}$ and the actual surface concentrations $(\Gamma)$ of the corresponding P-form. Total dissolved $\mathrm{P}$ (TDP) is the sum of DIP and DOP. In the second type of experiment (adsorption), increments of an equimolar solution of $\mathrm{H}_{2} \mathrm{PO}_{4} / \mathrm{HPO}_{4}{ }^{2-}$ were added to particle suspensions. As the interaction of DIP dominated the sorption, the resulting parameters were named $\mathrm{K}_{\max }$ and $\Gamma_{\max }$. Both kinds of titration processes were described with Langmuir-Isotherms (Stumm and Morgan, 1996; Müller and Sigg, 1990; 1992), where complexation constants $K_{n}$ are defined as:

$\equiv S+P \Leftrightarrow \equiv S P$

$K_{n}=\frac{[\equiv S P]}{[\equiv S][P]}$

and the sum of surface sites

$A \Gamma_{\max }=[\equiv S]+[\equiv S P]$

where $\mathrm{n}$ can be DIP, DOP or TDP, and A is the particle concentration in $\mathrm{g} \mathrm{L}^{-1}$, while $\Gamma$ is in $\mathrm{mol} \mathrm{g}^{-1}$. With the two parameters $\mathrm{K}_{\max }\left[\mathrm{L} \mathrm{\mu g}^{-1}\right]$ and $\Gamma_{\max }$ we are able to calculate the sorbed fraction $[\equiv \mathrm{SP}]$ from $[\mathrm{P}]$ and A (the concentration of dissolved $\mathrm{P}$ and the concentration of suspended particles) according to:

$[\equiv S P]=\frac{A \Gamma_{\max }}{1+\frac{1}{[P] K_{\max }}}$

\section{Sediment porewater measurements}

Four sediment cores were collected and transported to the shore, where the overlaying water was sampled to determine $\mathrm{O}_{2}$ profiles with the Winkler method and major ion profiles with standard photometric methods (DEW, 1996) or ion chromatography (Metrohm, Switzerland). Measurements of $\mathrm{O}_{2}$ profiles in the sediment porewater were performed using microoptodes (PreSens Regensburg, Germany) with a spatial resolution of $10 \mu \mathrm{m}$. The optode was moved with a micromanipulator (Newport Instruments, Switzerland) and a controller interface (MicroxTX3, Germany).

Concentration profiles of DIP, $\mathrm{NO}_{3}^{-}, \mathrm{SO}_{4}{ }^{2-}, \mathrm{Cl}^{-}$, and $\mathrm{Fe}(\mathrm{II})$ were analyzed in sediment porewater. The cores were transported to the laboratory and sectioned vertically in $0.5 \mathrm{~cm}$ slices within one day. The wet sediment was transferred to a $0.45 \mu \mathrm{m}$ membrane filter on a holder connected to a sucking flask, and the porewater was extracted by applying a vacuum. As neither free $\mathrm{HS}^{-}, \mathrm{Mn}^{2+}$ or $\mathrm{Fe}^{2+}$ was detected in earlier experiments, no measures were taken to prevent contact of oxygen with the porewater. Fluxes of ions and molecules to and from the sediment were calculated from vertical concentration profiles using a one-dimensional reaction-diffusion model (Müller et al., 2003).

\section{River monitoring and particle loads}

Hydraulic discharge Q (in $10 \mathrm{~min}$ intervals) and instantaneous suspended particle concentrations SPC (twice per week) in the Aare and Lütschine were recorded by the Swiss Hydrological Survey of the Federal Office for the Environment (FOEN) as part of their national monitoring program. The products of $\mathrm{Q}$ and SPC provide therefore only 104 discrete estimates of suspended particle transport per annum, necessitating higher spatial resolution for an appropriate integration to annual loads (Crawford, 1991; Cohn, 1995). However, rating curves - revealing important intrinsic deficits - have been recently optimized by Finger et al. (2006) to include a timedependent "correction" to match with the measured instant particle concentrations. As test runs indicate, the adaptive rating curve reproduces annual suspended particle loads with accuracy better than $20 \%$ (Lütschine) and $30 \%$ (Aare) and long-term averages within only a few percent.

Phosphate measurements from Aare and Lütschine water samples, collected diurnally between July and December 2005 were used to establish a relation between discharge $\mathrm{Q}\left[\mathrm{m}^{3} \mathrm{~s}^{-1}\right]$ and phosphate concentrations $\mathrm{C}_{\mathrm{SRP}}\left[\mu \mathrm{gP} \mathrm{L}^{-1}\right]$. The general function

$\mathrm{C}_{\mathrm{SRP}}=\mathrm{a}+\mathrm{bQ}^{\mathrm{c}}$

was fitted with the parameters $\mathrm{a}=1.75 \mu \mathrm{gP} \mathrm{\textrm {L } ^ { - 1 }}, \mathrm{b}=$ 0.13 , and $\mathrm{c}=0.66$ for the Aare, and $\mathrm{a}=0, \mathrm{~b}=0.36$, and $\mathrm{c}=0.44$ for the Lütschine. 


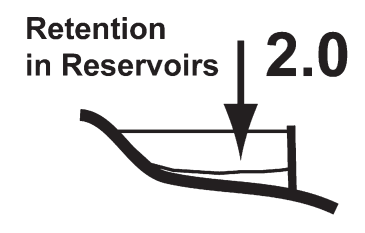

Atmosph. Deposition

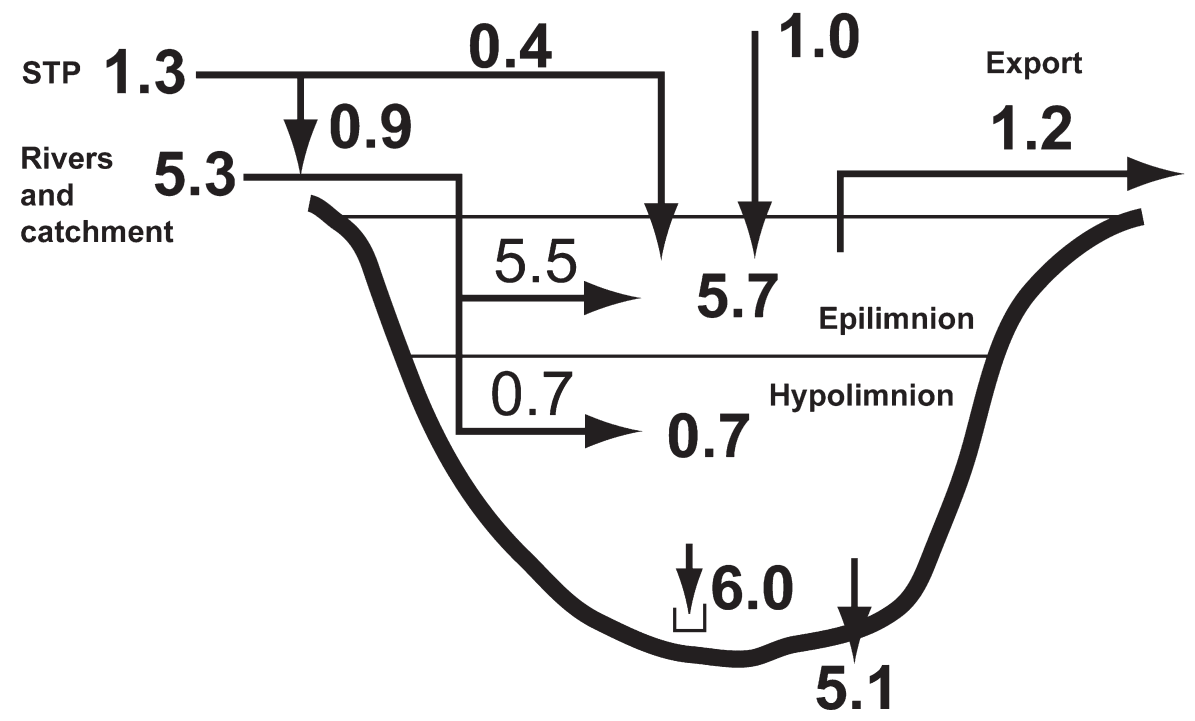

Figure 2. Detailed budget and fluxes of bio-P in the catchment of Lake Brienz. Fluxes are given in [tP yr ${ }^{-1}$. Import is made up of the contributions of the tributaries and the remaining catchment $(4.15+1.29+0.76=6.2)$, direct input from STPs $(0.4)$, and atmosphere $(1.0)$ resulting in $7.6 \mathrm{t} \mathrm{yr}^{-1}$. Alternatively, the export load is estimated from the net sedimentation and the outflow $(5.1+1.2=6.3)$. Averaging load and export, we estimate a mean bio-P load of $7.0 \mathrm{t} \mathrm{yr}^{-1}$.

\section{Results and discussion}

A detailed budget of bio-available $\mathrm{P}$ in Lake Brienz will be presented, making use of the different types of independent data sets, and discussed below. The values for the corresponding fluxes of bio-P will finally lead to the construction of Figure 2.

\section{Bio-available phosphate from aquatic particles}

The characterization of the chemical forms in which particulate $\mathrm{P}$ is present was determined with a sequential extraction treatment as described in detail in Wüest et al. (unpubl. data). The determination of the availability of dissolved $\mathrm{P}$ from particulate matter that can be used by biota was accomplished through a passive desorption (Müller et al., 2006a). In Table 1 surface binding constants from the interaction of dissolved $\mathrm{P}$ with particle surfaces of various origins are summarized and compared to sorption capacities from both methods. The definition of 'bio-availability' is operational for the passive desorption since only DIP is analyzed. The method of sequential extraction, however, characterizes a group of substances and, indirectly, their reactivity. For the selection in Table 1 we chose the fraction released after treatment with 1 $\mathrm{M} \mathrm{NaOH}$ which is characterized as (reversibly) bound to iron oxides and, thus, potentially bio-available.
Values of the latter method were 1.5 to 2.5 times higher than for the passive desorption.

Both methods are complementary in that the sequential extraction exerts chemical forces on particulate $\mathrm{P}$, while the method of adsorption / desorption experiments is 'milder' since mere changes of concentration ratios between particles and $\mathrm{P}$ cause a shift in the chemical equilibria. The treatment of particles with aggressive chemicals such as $\mathrm{NaOH}$ and $\mathrm{HCl}$ changes the ionic strength, affecting the composition, aggregation and exposed particle surfaces and causing a larger fraction of potentially dissolvable $\mathrm{P}$ to be released to solution than would occur under natural conditions. The method of passive desorption is closest to the natural process of dilution; hence, we consider it to be the most appropriate method.

Table 2 shows a concise summary of a dataset published in Müller et al. (2006a). The data, clustering in three groups, are characterized as (a) sediment particles of the upstream alpine reservoirs with small surface areas ( 2 to $3 \mathrm{~m}^{2} \mathrm{~g}^{-1}$ ) and low content of organic carbon, calcite, and iron, (b) suspended particles from the two main tributaries, sediment traps and surface sediments of Lake Brienz with specific surface areas of 7 to $10 \mathrm{~m}^{2} \mathrm{~g}^{-1}$, and (c) Lake Brienz sediment particles from older strata $(>15 \mathrm{yr})$. Desorption from surfaces was determined for DIP, DOP, and TDP, whereas 
Table 1. Fractions of bio-available P on particulate matter determined with the method of passive desorption ( $\boldsymbol{\Gamma}_{\mathbf{T D B}}$ Müller et al., 2006a) and sequential extractions (reversibly bound $\mathrm{P}$, extracted with $1 \mathrm{M} \mathrm{NaOH}$, Wüest et al., unpubl. data).

\begin{tabular}{lll}
\hline Sample & $\Gamma_{\text {TDP }}$ & Rev. bound P \\
\cline { 2 - 3 } & $\mathrm{mmol} \mathrm{kg}^{-1}$ & $\mathrm{mmol} \mathrm{kg}^{-1}$ \\
\hline Grimsel Inlet Reservoir (not used for aver.) & 0.21 & 0.31 \\
Grimsel Reservoir, center & 0.28 & 0.68 \\
Grimsel Reservoir, outlet & 0.49 & 0.84 \\
Räterichsboden Reservoir & 0.38 & 0.84 \\
Oberaarsee Reservoir & 0.51 & - \\
Lake Brienz Trap BR03-1, 50 m & 0.54 & 1.33 \\
Lake Brienz Trap BR03-1, $255 \mathrm{~m}$ & 0.47 & 1.36 \\
Lake Brienz Sediment BR04, $20 \mathrm{~m}(0-0.5 \mathrm{~cm})$ & 0.65 & 1.12 \\
Lake Brienz Sediment BR04, $212 \mathrm{~m}(0-0.5 \mathrm{~cm})$ & 0.63 & 1.12
\end{tabular}

Table 2. Surface sorption constants $(\log K)$, content of TDP sorbed to particles $\left(\Gamma_{\mathrm{TDP}}\right)$, and maximum binding capacities $\left(\Gamma_{\max }\right)$ for the sorption of DIP, DOP and TDP to a variety of aquatic particles. $\mathrm{n}$ indicates the number of individual samples used for the calculation of averages. Selected data from Müller et al. (2006a).

\begin{tabular}{|c|c|c|c|c|c|c|}
\hline \multirow[b]{2}{*}{ Origin of samples } & \multicolumn{4}{|c|}{ Desorption experiments } & \multicolumn{2}{|c|}{ Adsorption experiments } \\
\hline & $\log \mathrm{K}_{\mathrm{DIP}}$ & $\log \mathrm{K}_{\mathrm{DOP}}$ & $\log \mathrm{K}_{\mathrm{TDP}}$ & $\begin{array}{l}\Gamma_{\mathrm{TDP}} \\
{\left[\mathrm{mmol} \mathrm{kg}{ }^{-1}\right]}\end{array}$ & $\log K_{\max }$ & $\begin{array}{l}\Gamma_{\max } \\
{[\mathrm{mmol} \mathrm{kg}}\end{array}$ \\
\hline $\begin{array}{l}\text { Upstream alpine reservoir sediments }(\mathrm{n}=4) \\
\text { Lake Brienz: }\end{array}$ & $6.49 \pm 0.27$ & $6.98 \pm 0.44$ & $6.40 \pm 0.23$ & $0.41 \pm 0.11$ & $6.37 \pm 0.22$ & $0.61 \pm 0.16$ \\
\hline $\begin{array}{l}\text { Suspended particles and surface sediments }(\mathrm{n}=9) \\
\text { Lake Brienz: }\end{array}$ & $6.34 \pm 0.37$ & $6.22 \pm 0.67$ & $5.82 \pm 0.25$ & $0.60 \pm 0.18$ & $5.75 \pm 0.14$ & $1.35 \pm 0.21$ \\
\hline Older sediments $(>15$ yrs; $\mathrm{n}=2$ ) & $5.73 \pm 0.14$ & $6.48 \pm 0.49$ & $5.53 \pm 0.04$ & $1.10 \pm 0.08$ & $5.66 \pm 0.08$ & $1.21 \pm 0.06$ \\
\hline
\end{tabular}

adsorption experiments were dominated by the sorption of DIP.

Excellent agreement was achieved between surface binding constants from adsorption $\left(\mathrm{K}_{\max }\right)$ and desorption experiments $\left(\mathrm{K}_{\mathrm{TDB}}\right.$ Table 2$)$. From a surface chemical point of view, this suggests that dissolved $\mathrm{P}$ forms an inner-sphere type bond with relatively uniform surface sites, and that steric hindrance due to increasing surface coverage was not observed.

\section{Retention of bio-available phosphorus in upstream alpine reservoirs}

Anselmetti et al. (2007) estimated the average annual deposition of particulate material in the hydropower reservoirs of the catchment to be $232 \mathrm{kt}$ (average for 1930 to 2003). The total potential bio-P reversibly bound on these particles was determined from 4 samples (Müller et al., 2006a) and resulted in an average of $0.41 \mathrm{mmol} \mathrm{kg}^{-1}$ (Table 2). However, as given in Table 1, values of desorbable bio-P are smaller for sediments closer to the inflow due to larger grain sizes, and higher for those at the center and outflow of the reservoir. We estimate that about one third of the particulate loads deposited in the reservoirs, especially near the glacial river entrances, consists of coarse material, sand and even boulders (Anselmetti et al., 2007). Hence, considering the remaining two thirds of the total particle load of $232 \mathrm{kt}$ in the calculation of reversibly sorbed $\mathrm{P}$, we estimate an average deposition

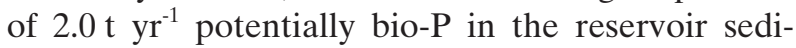
ments.

\section{Bio-available phosphorus load from Aare and Lütschine}

Equation (4) was used to calculate the fraction of bio-P that was transported sorbed to particle surfaces in the rivers Aare and Lütschine. This fraction escapes the analytical detection of bio-P, which is usually considered as the amount that is measured in samples filtered through a $0.45 \mu \mathrm{m}$ pore size membrane. Discharge measurements with a time resolution of $10 \mathrm{~min}$ for the years 2003 and 2004 were used, and particle loads were modeled as described above. Table 3 summarizes the results, showing that the average annual loads of bio-P were $4.15 \mathrm{t}$ for the Aare and $1.29 \mathrm{t}$ for the Lütschine, where $7.4 \%$ and $24.8 \%$ of the bio-P was transported in particulate form, respectively (Müller et al., 2006a). The catchments of the Aare and Lütschine cover $994.1 \mathrm{~km}^{2}$, leaving $139.9 \mathrm{~km}^{2}$ to other torrents and brooks, which we add proportionately to our P-balance of $5.44 \mathrm{t} \mathrm{yr}^{-1}\left(0.76 \mathrm{t} \mathrm{yr}^{-1}\right)$, yielding a total of $6.2 \mathrm{t} \mathrm{yr}^{-1}$. A further load from STPs of $0.4 \mathrm{t} \mathrm{yr}^{-1}$ that is diverted into the lake directly (and not by way of the two rivers) adds

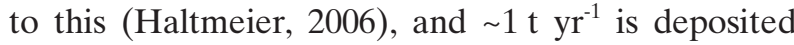
from the atmosphere directly onto the lake surface (Prasuhn and Mohni, 2003). All contributions sum up to an estimated bio-P input of $7.6 \mathrm{t} \mathrm{yr}^{-1}$ (Fig. 2). 


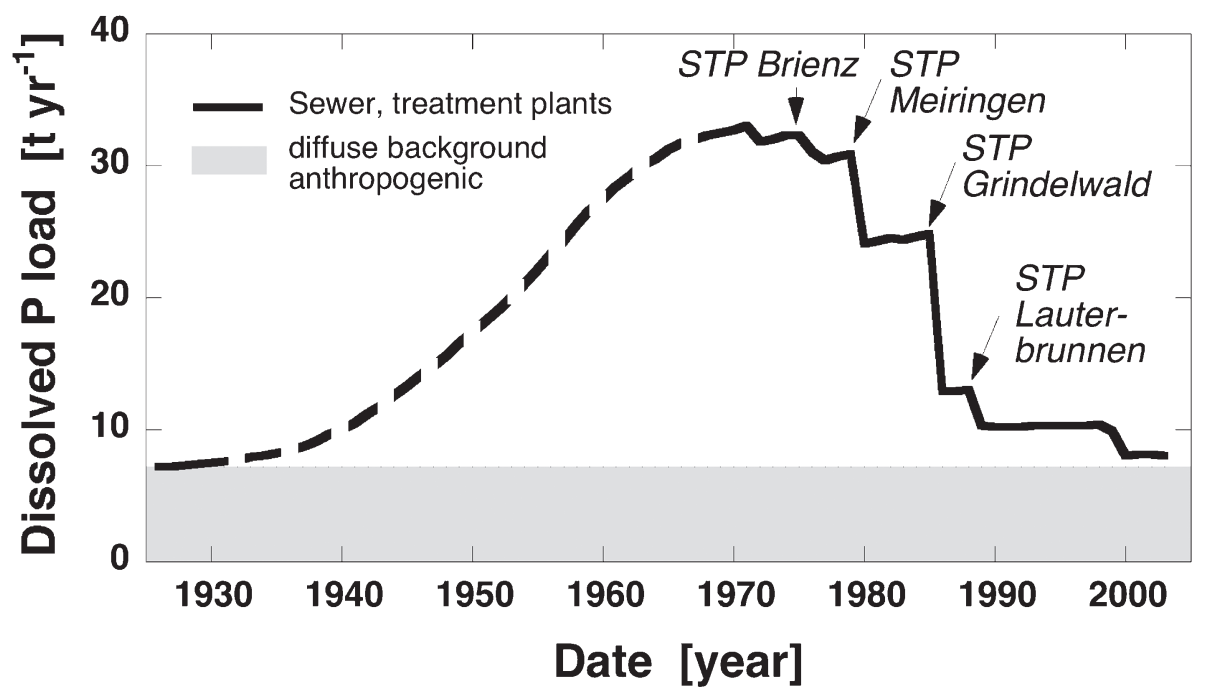

Figure 3. Temporal development of the dissolved P load to Lake Brienz. The P export from the sewage treatment plants (STPs) (since 1970 ) is monitored by the Office of Water Protection and Waste Management of the Canton of Bern. No data on P loads from sewers were available until 1970, and this part of the line was sketched as a probable development (broken line). The background load of $7.0 \mathrm{tP}$ yr ${ }^{-1} \mathrm{was}$ used as estimated by this work. Arrows mark the construction of STPs in the catchment.

\section{River intrusion depths}

Depending on the river and lake water densities, the tributaries to Lake Brienz may be light - or warm enough to mix with the epilimnion, or they may plunge and flow along the steep slopes to the deep reaches. Of all bio-P imported to Lake Brienz only the fraction remaining in the trophogenic surface layer will be available for primary production. The Lütschine is unaffected by hydropower production, and thus its intrusion behavior is not sensitive to anthropogenic activities. In contrary, the flow regime of the Aare is dominated by hydropower operations such as hydropeaking. Today, the water discharge between November and March is twice as much compared to pre-dam conditions (Finger et al., 2006). In summer, however, snow- and glacier-melt as well as some of the floodwaters are collected in the reservoirs. The particle retention in the reservoirs leads to a significant reduction of the sediment loads in the Aare compared to pre-dam conditions (Anselmetti et al., 2007). Furthermore, the decrease of high flow events (due to water retention in the reservoir) leads to more frequent intrusions of the Aare into the surface layer. According to model calculations by Finger et al. (2006) the Aare discharges $90 \%$ of its water load into the epilimnion of Lake Brienz. In comparison the unaffected Lütschine intrudes only $80 \%$ into the epilimnion. About $52 \%\left(158 \mathrm{kt} \mathrm{yr}^{-1}\right)$ of the annual particle load of $302 \mathrm{kt} \mathrm{yr}^{-1}$ enter the epilimnion, while $48 \%\left(144 \mathrm{kt} \mathrm{yr}^{-1}\right)$ plunge to the hypolimnion and settle out without affecting the productive zone of the lake. Considering the Q-C rating curves above (eq. 5), we calculate that of the river-born $6.2 \mathrm{t} \mathrm{yr}^{-1} \mathrm{P}$, approx- imately $5.5 \mathrm{t} \mathrm{yr}^{-1}$ flow into the productive surface layer and $0.7 \mathrm{t} \mathrm{yr}^{-1}$ plunge to the hypolimnion. The details of the effect of the intrusion depths on the particle and $\mathrm{P}$ distribution in the lake, as well as the subsequent changes in productivity as a function of the hydropower operation, are provided in the companion paper by Finger et al. (2007).

\section{Contribution from sewage treatment plants}

The construction of a sewer system in the lake catchment in the 1930s helped to remove sewage from the villages, discharging it into the lake and leading to a subsequent increase in nutrient levels. This can be seen in the reconstruction of the input of TDP in Figure 3 (broken line, interpolated as probable development). The outflow of TP from STPs has been monitored by the Office of Water Protection and Waste Management of the Canton of Bern (GBL) since 1970 and is well known. The construction of STPs and their subsequent upgrading with $\mathrm{Fe}$-induced P-precipitation helped efficiently reduce the eutrophication of the lake. It is apparent from Figure 3 that the $\mathrm{P}$ content of Lake Brienz closely matches with the operation of the STP in its catchment. An estimation of pre-dam P loads is difficult, as the accuracy of SRP monitoring data was not yet sufficient at these low concentrations.

The TP load from STPs, dissolved as well as particulate, is assumed to be available to algal growth since P-containing particles consist of bacterial flocs that decompose in receiving waters. However, it has been estimated that only one third of the P released to surface waters becomes bio-available for STPs run- 
ning $\mathrm{P}$ co-precipitation with $\mathrm{Fe}$ or $\mathrm{Al}$ salts (T. Haltmeier, pers. comm.). The average export load of bio-P by STPs into Lake Brienz was therefore only $0.88 \mathrm{t} \mathrm{yr}^{-1}$ for 2001 to 2003 (Haltmeier, 2006). The additional contribution from floodwater overflow

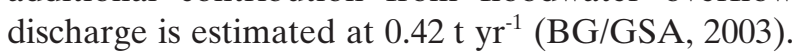
Hence, the part of bio-P from STP discharge amounts to only $1.3 \mathrm{t} \mathrm{yr}^{-1}$. Most of this load enters via the two main rivers, and only $0.4 \mathrm{t} \mathrm{yr}^{-1}$ flows directly into the lake.

\section{Estimation of phosphorus loads with GIS model}

In a recent internal report, Prasuhn (2005) estimated the losses of biologically active $\mathrm{P}$ from the catchment of Lake Brienz to the surface waters, and finally into the lake. These fluxes are based on a general model by Prasuhn and Mohni (2003) developed to quantify the effects of different farming practices on the release of $\mathrm{P}$ in the Canton of Bern. In spite of the optimization of the original model for soils with high $\mathrm{P}$ content, resulting in large uncertainties for $\mathrm{P}$ export from the extremely P-poor soils in the rocky and glaciated catchment of Lake Brienz, the study concluded that the load of dissolved $\mathrm{P}$ from diffuse sources to the lake was smaller than $10 \mathrm{t} \mathrm{yr}^{-1}$. This supports our finding of $7.6 \mathrm{t} \mathrm{yr}^{-1}$ input by rivers, STPs and precipitation. For the atmospheric deposition a concentration in the rainwater of $20 \mu \mathrm{gP} \mathrm{L}^{-1}\left(0.65 \mu \mathrm{mol} \mathrm{L}^{-1}\right)$ and an average rainfall of $1600 \mathrm{~mm} \mathrm{yr}^{-1}$ were assumed, resulting in a direct deposition of $0.95 \mathrm{t} \mathrm{P}$ on the lake surface (Prasuhn and Mohni, 2003).

\section{Surface outflow}

The $\mathrm{P}$ outflow to the underlying Lake Thun was estimated based on an average $P$ concentration in the epilimnion of $0.5 \mu \mathrm{g} \mathrm{L}^{-1}$ and the hydraulic discharge of $\sim 2.0 \mathrm{~km}^{3} \mathrm{yr}^{-1}$ (Wüest et al., in prep.), including the bio$\mathrm{P}$ associated with the particles exported from the lake $\left(10 \mathrm{kt} \mathrm{yr}^{-1}\right)$ given in Table $1\left(0.54 \mathrm{mmol} \mathrm{kg}^{-1}\right)$. This leads to a total of $1.2 \mathrm{t}$ of bio-P exported annually from the lake.

\section{Gross sedimentation of phosphorus and carbon}

Average gross sedimentation rates during 2003 and 2004 determined from sediment traps exposed at $50 \mathrm{~m}$ and $255 \mathrm{~m}$ depths were 95 and $320 \mathrm{kt} \mathrm{yr}^{-1}$, respectively (Finger et al., 2006). Using a mean value of $0.60 \mathrm{mmol}$ $\mathrm{P} \mathrm{kg}^{-1}$ for settling particles and suspended sediments (Table 2) results in $6.0 \mathrm{t} \mathrm{yr}^{-1}\left(0.2 \mathrm{~g} \mathrm{~m}^{-2} \mathrm{yr}^{-1}\right)$ of bio-P at $255 \mathrm{~m}$ depth. This value matches well with the annual net import to the lake of $6.4 \mathrm{t} \mathrm{yr}^{-1}$ (6.2 from rivers, 0.4 direct input from STP, 1.0 from precipitation and 1.2 exported to Lake Thun). But only $1.8 \mathrm{t} \mathrm{yr}^{-1}\left(0.06 \mathrm{~g} \mathrm{~m}^{-2}\right.$ $\mathrm{yr}^{-1}$ ) of desorbable bio-P were confirmed with the material from the $50 \mathrm{~m}$ traps, which does not reflect the amount of $\mathrm{P}$ assimilated in the epilimnion, probably because the settled material has only partly decomposed and is not yet available in desorption experiments.

The amount of organic matter collected in the $50 \mathrm{~m}$ trap, settling from the trophogenic zone, indicates the net system production, or the net export rate, and

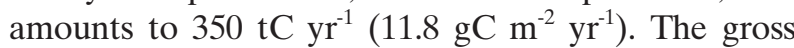
sedimentation of organic carbon extrapolated in the bottom sediment trap was $2250 \mathrm{tC} \mathrm{yr}^{-1}\left(75.5 \mathrm{gC} \mathrm{m}^{-2} \mathrm{yr}^{-1}\right)$. The large difference between the system export production and gross sedimentation (sum of diagenetic mineralization in the sediment and net sedimentation) is caused by the large amount of allochthonous material imported, such as leaf litter, wood, soil particles, etc. These materials enter the lake mainly during floods where both, the Aare and Lütschine, plunge and intrude into the deep reaches of the lake. Hence, less of this refractory biomass is captured in the upper sediment traps at $50 \mathrm{~m}$ depth.

\section{Net sedimentation}

The sedimentation rate determined from the cores at $20 \mathrm{~m}$ and $212 \mathrm{~m}$ depth $\left({ }^{137} \mathrm{Cs}\right.$ dated $)$ were 0.31 and $0.64 \mathrm{~cm} \mathrm{yr}^{-1}$, respectively. The core from the shallow depth provided annual layers of even thickness, while the deeper core showed irregular sedimentation dominated by single floodwater events and turbidity currents; hence only the top $5 \mathrm{~cm}$ could be attributed to distinct years (1997 to 2004). Applying a sediment particle density of $2.60 \mathrm{~g} \mathrm{~cm}^{-3}$ resulted in average annual depositions of 111 and $246 \mathrm{kt}$ of particulate matter, respectively, in 20 and $212 \mathrm{~m}$ depth. These mass accumulation rates agree reasonably well with the gross sedimentation determined from particle traps at $50 \mathrm{~m}\left(95 \mathrm{kt} \mathrm{yr}^{-1}\right)$ and $255 \mathrm{~m}\left(320 \mathrm{kt} \mathrm{yr}^{-1}\right)$. From the discrepancy of the input-output balance we estimate the error to be less than $15 \%$ (Finger et al., 2006).

The net sedimentation of bio-P at $212 \mathrm{~m}$ depth calculated with the experimental result for desorbable $\mathrm{P}\left(0.63 \mathrm{mmol} \mathrm{kg}^{-1}\right.$, Table 1$)$ was $4.8 \mathrm{tP} \mathrm{yr}^{-1}$. Using the average particle load estimated from an input-output balance $\left(292 \mathrm{kt} \mathrm{yr}^{-1}\right)$, we calculate a net sedimentation rate of $5.4 \mathrm{tP} \mathrm{yr}^{-1}$. We will use $5.1 \mathrm{tP} \mathrm{yr}^{-1}\left(0.17 \mathrm{gP} \mathrm{m}^{-2} \mathrm{yr}^{-1}\right)$ as the average for the net sedimentation of bio-P (Fig. 2). The difference between gross and net sed-

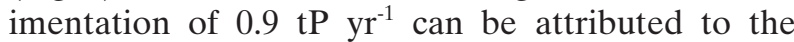
mineralization of settled organic matter (Wüest et al., unpubl. data); however, it is certainly within the error of the methods used to determine net sedimentation.

The sum of bio-P exports by surface outflow and burial in the sediment (i.e., $1.2+5.1=6.3 \mathrm{t} \mathrm{yr}^{-1}$ ) provides an alternative estimate for the bio-P load to Lake Brienz. We consider $7.0 \mathrm{tP} \mathrm{yr}^{-1}\left(0.24 \mathrm{gP} \mathrm{m}^{-2} \mathrm{yr}^{-1}\right)$, 
Table 3. Annual input loads of bio-P and the fraction sorbed to suspended particles of Aare and Lütschine for the years 2003 and 2004. Catchment area is given in parentheses.

\begin{tabular}{|c|c|c|c|c|c|}
\hline & \multicolumn{2}{|c|}{ Aare $\left(603.0\right.$ km$\left.^{2}\right)$} & \multicolumn{2}{|c|}{ Lütschine (391.1 km²) } & \multirow{2}{*}{$\begin{array}{l}\text { Other }\left(\mathbf{1 3 9 . 9} \mathbf{k m}^{\mathbf{2}}\right) \\
\text { bio-P load } \\
\text { t yr }^{-1}\end{array}$} \\
\hline & $\begin{array}{l}\text { bio-P load } \\
\text { t yr }^{-1}\end{array}$ & $\begin{array}{l}\text { fraction sorbed } \\
\%\end{array}$ & $\begin{array}{l}\text { bio-P load } \\
\text { t yr }^{-1}\end{array}$ & $\begin{array}{l}\text { fraction sorbed } \\
\%\end{array}$ & \\
\hline 2003 & 4.18 & 4.9 & 1.40 & 29.2 & \\
\hline 2004 & 4.12 & 9.8 & 1.18 & 20.4 & \\
\hline average & 4.15 & 7.4 & 1.29 & 24.8 & 0.76 \\
\hline
\end{tabular}

Table 4. Fluxes of $\mathrm{O}_{2}, \mathrm{NO}_{3}^{-}$, and $\mathrm{SO}_{4}{ }^{2-}$ into the sediment and penetration depths of $\mathrm{O}_{2}$ from four cores from Lake Brienz. Values for $\mathrm{O}_{2}$ were calculated from two repetitions in each core.

\begin{tabular}{|c|c|c|c|c|c|}
\hline \multirow[b]{2}{*}{ Core code } & \multirow[t]{2}{*}{ Units } & \multicolumn{2}{|c|}{6 May 2004} & \multicolumn{2}{|c|}{30 Nov 2004} \\
\hline & & BR04-3A & BR04-3D & BR04-24 & BR04-26 \\
\hline depth & $\mathrm{m}$ & 20 & 212 & 23 & 210 \\
\hline $\mathrm{O}_{2}$ flux & $\mathrm{mmol} \mathrm{m} \mathrm{d}^{-1}$ & 3.6 & 3.5 & 3.5 & 4.2 \\
\hline $\mathrm{O}_{2}$ penetration depth & $\mathrm{mm}$ & 24.5 & 16.5 & 28 & 13.2 \\
\hline $\mathrm{NO}_{3}^{-}$flux & $\mathrm{mmol} \mathrm{m} \mathrm{m}^{-2}$ & 0.12 & 0.26 & 0.13 & 0.23 \\
\hline $\mathrm{SO}_{4}^{2-}$ flux & $\mathrm{mmol} \mathrm{m} \mathrm{m}^{-2} \mathrm{~d}^{-1}$ & 0.10 & 0.18 & 0.09 & 0.13 \\
\hline
\end{tabular}

which is the average of the two above estimates (7.6

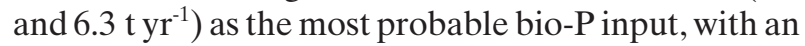
uncertainty of $\pm 10 \%$.

The net sedimentation of bio-P at $20 \mathrm{~m}$ depth calculated with the corresponding $\Gamma_{\mathrm{TP}}$ (Table 1) was $2.2 \mathrm{tP} \mathrm{yr}^{-1}\left(0.07 \mathrm{~g} \mathrm{~m}^{-2} \mathrm{yr}^{-1}\right)$. This corresponds well with the $1.8 \mathrm{tP} \mathrm{yr}^{-1}$ determined for the net export rate of bio$\mathrm{P}$ by analyzing the material from the particle traps.

The net sedimentation rate of organic carbon determined from the deep core was $1640 \mathrm{tC} \mathrm{yr}^{-1}(55.0$ $\left.\mathrm{gC} \mathrm{m}^{-2} \mathrm{yr}^{-1}\right)$. The gross sedimentation from sediment

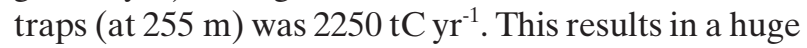
burial efficiency for organic carbon of $73 \%$, suggesting that the organic material imported to the lake is very refractory and difficult to degrade. The trap material consists of allochthonous particles from floodwater intrusions, which are often soil particles, leaf litter, wood debris, etc.

Mineralization processes and release from sediments Oxygen penetrates deep into the sediments of Lake Brienz and, consequently, $\mathrm{O}_{2}$ consumption is low and similar to other ultra-oligotrophic lakes such as Lake Baikal (Maerki et al., 2006). Fluxes of $\mathrm{O}_{2}$ into the sediment are substantially lower than estimates from other oligotrophic Swiss lakes such as Lake Lucerne (8 to $11 \mathrm{mmol} \mathrm{m}^{-2} \mathrm{~d}^{-1}$, Müller et al., 2006b) or mesotrophic lakes such as Lake Alpnach $\left(8\right.$ to $20 \mathrm{mmol} \mathrm{m}^{-2} \mathrm{~d}^{-1}$, Müller et al., 2002). Figure 4 depicts $\mathrm{O}_{2}$ concentration profiles measured in the porewaters of two sediment cores from $20 \mathrm{~m}$ and $212 \mathrm{~m}$ depth. The fluxes of $\mathrm{O}_{2}$, $\mathrm{NO}_{3}{ }^{-}$, and $\mathrm{SO}_{4}{ }^{2-}$ across the sediment-water interface are summarized in Table 4, including $\mathrm{O}_{2}$ penetration depths from sediments at shallow as well as from deep locations. Shifted further downwards, the profiles of $\mathrm{NO}_{3}{ }^{-}$and $\mathrm{SO}_{4}{ }^{2-}$ indicate consumption fluxes of 0.23 to 0.26 and 0.13 to $0.18 \mathrm{mmol} \mathrm{m}^{-2} \mathrm{~d}^{-1}$, respectively. Figure 5 shows that the zones of consumption are narrower at greater depth because of the larger sedimentation rate. The marked peak of $4.5 \mu \mathrm{mol} \mathrm{L}^{-1}$ dissolved $\mathrm{P}$ within a zone of only $1 \mathrm{~cm}$ in Figure $5 \mathrm{c}$ occurs right below the disappearance of $\mathrm{O}_{2}$ and $\mathrm{NO}_{3}{ }^{-}$and indicates the release of $\mathrm{P}$ bound to particulate Fe-oxides dissolved by reductive dissolution. However, increases of the analytical concentrations of dissolved Fe(II) or $\mathrm{Mn}(\mathrm{II})$ were not observed. The $\mathrm{P}$ released in this zone of steep redox gradient is scavenged in the immediate vicinity above and does not diffuse out of the sediment and into the bottom water.

The mineralization of organic material was estimated from the consumption of $\mathrm{O}_{2}, \mathrm{NO}_{3}{ }^{-}$and $\mathrm{SO}_{4}{ }^{2-}$. Since the lake has steep walls and a large deep plain, we used only the averaged data from the deeper cores in Table 4. Table 5 summarizes the fluxes of oxidants and stoichiometries used in the calculations. From these oxidation rates, we estimate a net $\mathrm{C}$ assimilation rate of $15.7 \mathrm{gC} \mathrm{m}^{-2} \mathrm{yr}^{-1}$. This corresponds to the

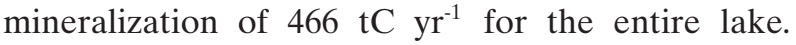
Assuming an ideal Redfield ratio of $\mathrm{C}: \mathrm{P}=106$ we estimate a turnover of $11.4 \mathrm{tP} \mathrm{yr}^{-1}$. Both values are overestimations, as allochthonous particulate organic material contributes to the mineralization. In addition, in ultra-oligotrophic waters the $\mathrm{C}: \mathrm{P}$ ratio is usually larger than the classical Redfield value of 106.

\section{Primary production and mineralization}

The determination of carbon assimilation rates leads to an annual gross production estimate of $67 \mathrm{gC} \mathrm{m}^{-2} \mathrm{yr}^{-1}$ 


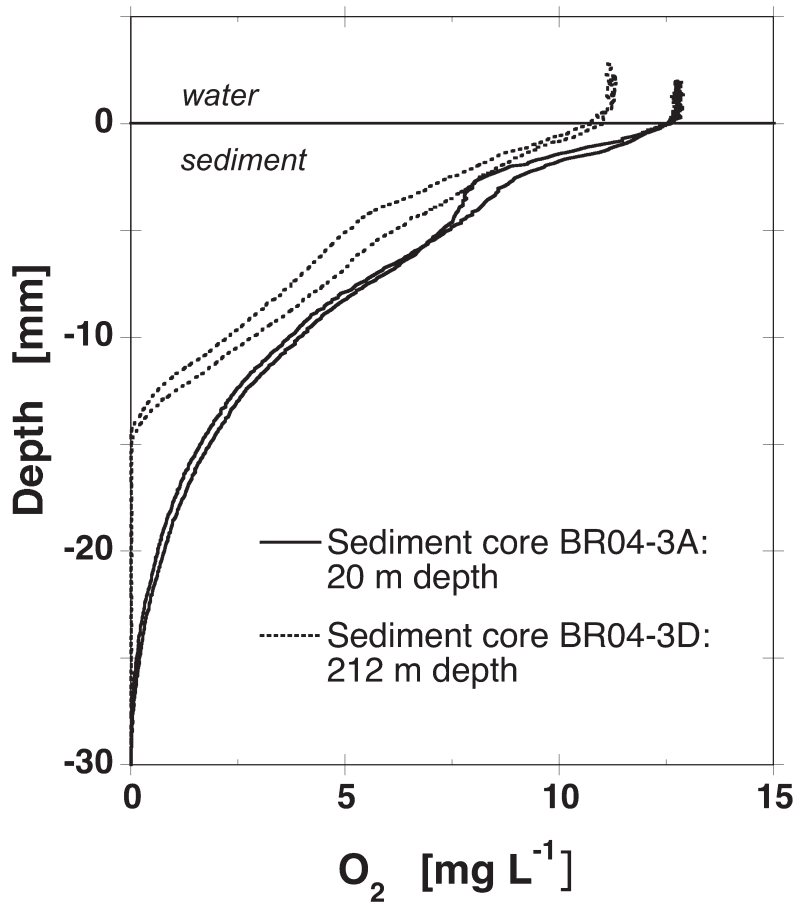

Figure 4. Porewater concentrations of $\mathrm{O}_{2}$ measured with microoptodes in two cores from Lake Brienz sampled 6 May 2004 at 20 m and $212 \mathrm{~m}$ depth, with two replicates in each core.

Table 5. Amount of organic carbon $\left(\mathrm{C}_{\text {org }}\right)$ mineralized with the oxidants $(\mathrm{Ox})$ determined in the porewater

\begin{tabular}{lllc}
\hline & $\begin{array}{l}\text { Flux Ox } \\
\mathrm{mmol} \mathrm{m}^{-2} \mathrm{~d}^{-1}\end{array}$ & Ox : $\mathbf{C}_{\text {org }}$ & $\begin{array}{c}\text { C-mineralization } \\
\mathrm{mmol} \mathrm{m}^{-2} \mathrm{~d}^{-1}\end{array}$ \\
\hline $\mathrm{O}_{2}$ & 3.85 & 0.77 & 2.96 \\
$\mathrm{NO}_{3}{ }^{-}$ & 0.245 & 1.25 & 0.31 \\
$\mathrm{SO}_{4}{ }^{2-}$ & 0.155 & 2 & 0.31 \\
\hline Sum C-mineralization rate $\left[\mathrm{mmol} \mathrm{m}^{-2} \mathrm{~d}^{-1}\right]$ & 3.58 \\
Mineralization $\left[\mathrm{gC} \mathrm{m}^{-2} \mathbf{y r}^{-1}\right]$ & 15.7 \\
Mineralization entire lake $\left[\mathbf{t C} \mathbf{~ y r ~}^{-1}\right]$ & $\mathbf{4 6 6}$ \\
\hline
\end{tabular}

(Finger et al., 2007). This is extremely low even compared with other deep, cold oligotrophic lakes such as Baikal; ca. $120 \mathrm{gC} \mathrm{m}^{-2} \mathrm{yr}^{-1}$ (Weiss et al., 1991; Obolkina, 2006), Walensee, 100 to $150 \mathrm{gC} \mathrm{m}^{-2} \mathrm{yr}^{-1}$ (Mieleitner and Reichert, 2006), Lake Tahoe, ca. 180 $\mathrm{gC} \mathrm{m}^{-2} \mathrm{yr}^{-1}$ (Chandra et al, 2006) or Lake Lucerne, 150 to $200 \mathrm{gC} \mathrm{m}^{-2} \mathrm{yr}^{-1}$ (P. Bossard, pers. comm.). Carbon assimilation is related to the consumption of bio-P, export flux of organic carbon from the trophic zone, and the mineralization rate of organic matter. However, as carbon and other nutrients are recycled many times in the trophogenic zone, especially of oligotrophic lakes, a direct comparison is not feasible. Nevertheless, based on experiences from other lakes, a primary production of $67 \mathrm{gC} \mathrm{m}^{-2} \mathrm{yr}^{-1}$ is reasonably consistent with the net system production of $11.8 \mathrm{gC} \mathrm{m}^{-2} \mathrm{yr}^{-1}$, which we calculated from sediment trap data $(50 \mathrm{~m})$.
The production of biomass is estimated from four independent sets of data. We compare (a) input of bio-P to the epilimnion, (b) net system production from $50 \mathrm{~m}$ deep traps, (c) mineralization rates estimated from pore water analysis, and (d) primary production measurements: We assume that all bio-P discharged into the epilimnion of the lake will eventually become available for primary production. This includes colloid-assimilated $\mathrm{P}$, as this fraction became available during the analytical procedure. Applying our model parameters, potentially desorbable bio-P sorbed to allochthonous particulate matter will desorb almost completely from particles after discharge to the lake as the suspended particles are diluted. Using the estimated $6.9 \mathrm{tP} \mathrm{yr}^{-1}$ (Fig. 2) that transit the trophic zone of the lake and assuming Redfield ratios of $\mathrm{C}: \mathrm{P}=106$, we calculate a net export rate of organic carbon of $9.4 \mathrm{gC} \mathrm{m}^{-2} \mathrm{yr}^{-1}$. This is consistent with the average net export rate or net system production of organic carbon of $11.8 \mathrm{gC} \mathrm{m}^{-2}$ $\mathrm{yr}^{-1}$ we determined from sediment traps at $50 \mathrm{~m}$ depth. Sediment porewater analysis reveals the mineralization of $15.7 \mathrm{gC} \mathrm{m}^{-2} \mathrm{yr}^{-1}$ by consumption of $\mathrm{O}_{2}, \mathrm{NO}_{3}^{-}$, and $\mathrm{SO}_{4}^{2-}$ (data from Table 5). These values can be compared to the measured primary productivity of $67 \mathrm{gC} \mathrm{m}^{-2} \mathrm{yr}^{-1}$ (Finger et al., 2007), resulting in a recycling efficiency of 4 to 7 . This is reasonable for oligotrophic lakes considering the varying concepts of the origin of the organic matter and, thus, supports the bio-P input estimate above.

\section{Past net phosphorus sedimentation}

From the 1950s until the mid 1980s, TP in the sediment increased by about $3 \mu \mathrm{mol} \mathrm{g}{ }^{-1}$, corresponding to a difference in the annual deposition rate of $27 \mathrm{t}$ (assuming an averaged annual particle load of 300 kt; Finger et al., 2006) and decreased markedly in the following 10 years. Figure 6 depicts the mass accumulation rate of $\mathrm{P}$ and $\mathrm{N}$ in the cores from 20 and $212 \mathrm{~m}$ depth. Increases have been caused by household sewage, and decreases can be attributed to the construction of STPs with P-precipitation. The profiles in Figure 6a indicate that TP is affected only to a maximum of $15 \%$ by short-term changes, whereas the largest fraction consists of a refractory mineral background of about $20 \mu \mathrm{mol} \mathrm{g}{ }^{-1}$. In fact, Haltmeier (2006) estimated an import of about $25 \mathrm{tP} \mathrm{yr}^{-1}$ by the sewer system in the 1970s, whereas nowadays the contribu-

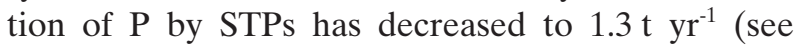
above). This estimate agrees very well with our finding of an increased load of $27 \mathrm{t} \mathrm{yr}^{-1}$ bio-P for the time of maximum concentration (Figure 6a). TN in the sediment (Figure 6b) originates mainly from organic matter and thus depicts the eutrophication history of the lake more sensitively than TP. Its content doubled 

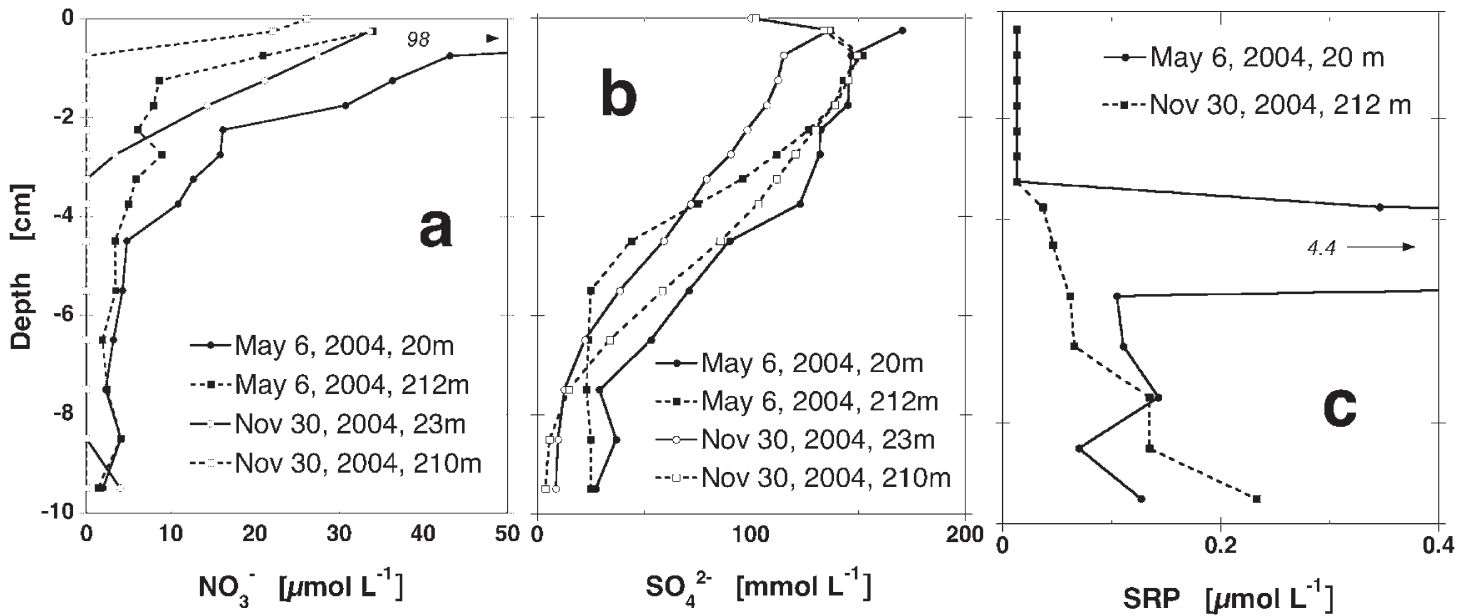

Figure 5. Porewater concentrations of (a) nitrate, (b) sulfate, and (c) SRP measured after filtration in the top $10 \mathrm{~cm}$ of the four cores from Lake Brienz sampled 6 May 2004 at 20 and $212 \mathrm{~m}$ depth, and 30 November 2004 at 23 and $210 \mathrm{~m}$ depth.
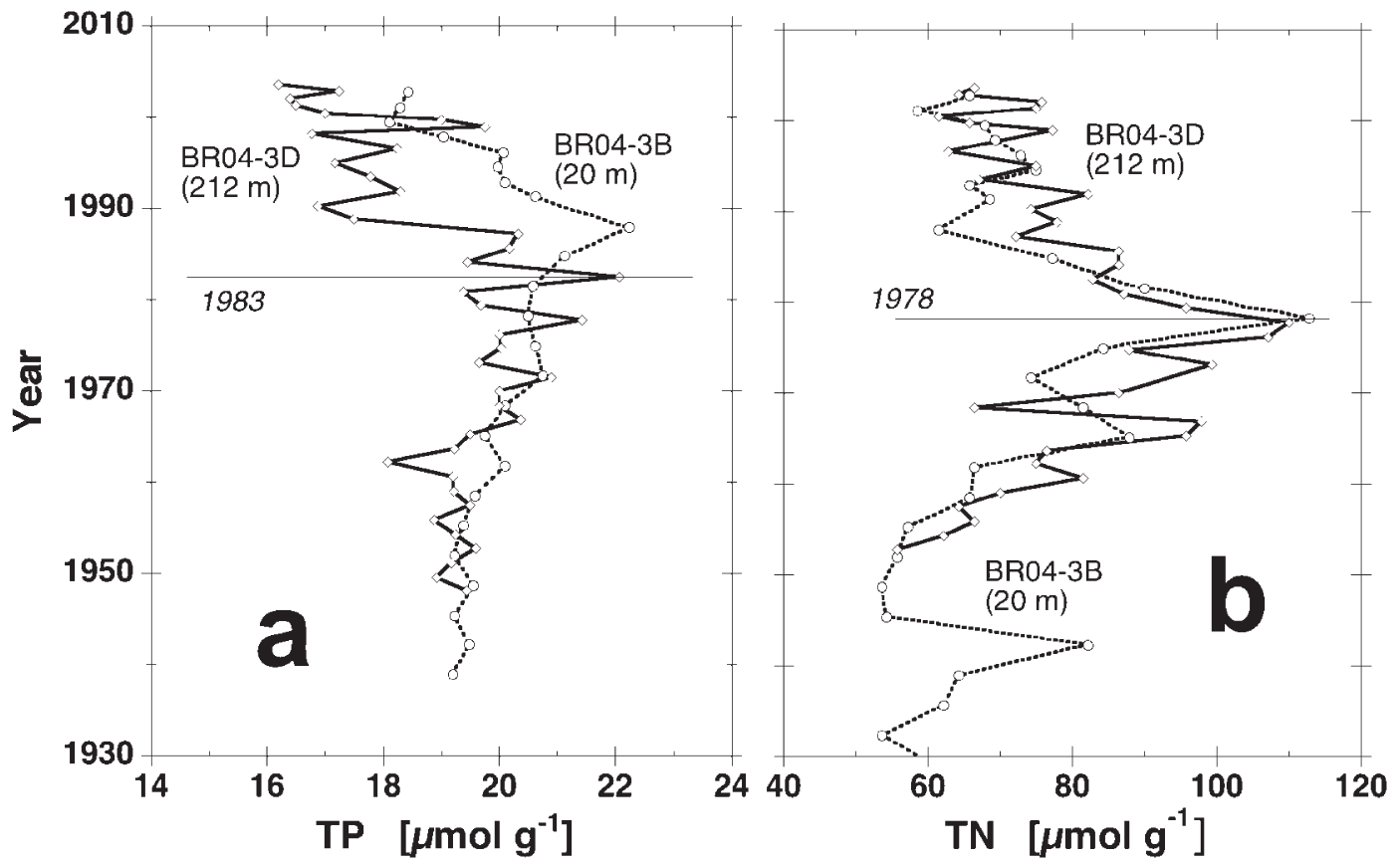

Figure 6. (a) TP and (b) TN in two sediment cores (BR04-3B, $20 \mathrm{~m}$ depth, and BR04-3D, $212 \mathrm{~m}$ depth) dated with ${ }^{137} \mathrm{Cs}$. Sedimentation rates were $0.31 \mathrm{~cm} \mathrm{yr}^{-1}(\mathrm{BR} 04-3 \mathrm{~B})$ and $0.64 \mathrm{~cm} \mathrm{yr}^{-1}(\mathrm{BR} 04-3 \mathrm{D})$.

since the 1950s and passed through a distinct maximum in 1978. Simultaneously with TN, the content of organic carbon peaks in 1978 as well (data not shown).

\section{Conclusions}

A detailed systems analysis quantifying the balance of bio-P in the ultra-oligotrophic Lake Brienz, charged with high loads of mineral particles, was undertaken. The combination of new methods specially developed to distinguish between bio-available and non-bio- available $\mathrm{P}$ in suspended particles and sediments, together with flux measurements by applying sediment traps, sediment coring, porewater analysis, primary productivity measurements, and particle dynamics allows the presentation of a well-defined budget of the $\mathrm{P}$ cycling in Lake Brienz (see Fig. 2).

We have been able to quantify the various present bio-P fluxes to and from Lake Brienz and the evolution of the net sedimentation during the last 70 years using sediment records and earlier monitoring data. From these we conclude that the contribution of the loads from household sewage dominated the bio-P 
budget in the second half of the $20^{\text {th }}$ century. Contributions from the glaciated catchments of the Aare and Lütschine were similar or smaller and have not changed significantly due to human activities in the catchment, apart from the construction of reservoirs in the 1930s. Balancing the two major anthropogenically influenced changes of bio-P, i.e. retention in the hydropower reservoirs $\left(\sim 2 \mathrm{t} \mathrm{yr}^{-1}\right)$ and contributions from current STPs $\left(1.3 \mathrm{t} \mathrm{yr}^{-1}\right)$, results in a net withdrawal in the order of $\sim 1 \mathrm{t} \mathrm{yr}^{-1}$, compared to a present gross flow of $7.0 \mathrm{t} \mathrm{yr}^{-1}$. The onset of eutrophication due to urban development in the 1950s could be explained with increased P-loads of up to $25 \mathrm{t} \mathrm{yr}^{-1}$ from STPs and agreed with measurements from sedimentary archives.

These extremely low bio-P fluxes consistently explain the low productivity of phytoplankton (Finger et al., 2007), zooplankton (Rellstab et al., 2007) and white fish (Müller et al., 2007b). The drop in biological productivity since the late 1970s is consistent with (a) the decrease of bio-P fluxes archived in the sediment, (b) the record of STP management, and (c) the few insitu observations.

\section{Acknowledgments}

We are indebted to Ruth Stierli, Wisi Zwyssig, Markus Zeh, Andreas Brand, Christine Vollenweider, and Henrietta Studer for their contributions and work in the field and the laboratory. Adrian Jakob (LHG/ FOEN) was greatly supportive in providing access to hydrological data. We acknowledge the constructive input by the three anonymous reviewers. The study was funded by the regional Government of Canton of Bern, Kraftwerke Oberhasli AG, Federal Office for the Environment (FOEN), the local lake shore communities and Eawag.

\section{References}

Anselmetti, F. S., R. Bühler, D. Finger, S. Girardclos, A. Lancini, C. Rellstab and M. Sturm, 2007. Effects of Alpine hydropower dams on particle transport and lacustrine sedimentation, Aquat. Sci. 69: doi 10.1007/s00027-007-0875-4.

BG/GSA, 2003. P und N Einträge aus Regenentlastungen in die Oberflächengewässer des Kantons Bern. Report.

Chandra, S., M. J. Vander Zanden, A. C. Heyvaert, B. C. Richards, B. C. Allen, and C. R. Goldman, 2006. The effects of cultural eutrophication on the coupling between pelagic primary producers and benthic consumers. Limnol. Oceanogr. 50: $1368-1376$.

Chanudet, V. and M. Filella, 2007. The fate of inorganic colloidal particles in Lake Brienz Aquat. Sci. 69: doi 10.1007/s00027007-0877-2.

Cohn, T. A., 1995. Recent advances in statistical methods for the estimation of sediment and nutrient transport in rivers. Rev. Geophys. 33: 1117 - 1123 .
Crawford, C. G., 1991. Estimation of suspended-sediment rating curves and mean suspended-sediment loads. J. Hydrol. 129: $331-348$.

DEW, 1996. Deutsche Einheitsverfahren zur Wasseruntersuchung (DEW), vol. 2, Wiley-VCH, Weinheim, Germany.

Finger, D., M. Schmid and A. Wüest, 2006. Effects of upstream hydropower operation on riverine particle transport and turbidity in downstream lakes. Water Resources Res. 42: W08429, doi:10.1029/2005WR004751.

Finger, D., P. Bossard, M. Schmid, L. Jaun, B. Müller, D. Steiner, E. Schäffer, M. Zeh and A. Wüest, 2007. Effects of alpine hydropower operations on primary production in a downstream lake. Aquat. Sci. 69: doi 10.1007/s00027-007-0873-6.

Haltmeier, T., 2006. Veränderungen im Oekosystem Brienzersee: Eintrag von gelöstem Phosphor. Internal report. Gewässerund Bodenschutzlabor des Kantons Bern (GBL). http:// www.eawag.ch/brienzersee.

Hupfer, M., R. Gächter and R. Giovanoli, 1995. Transformation of phosphorus species in settling seston and during early sediment diagenesis. Aquatic Sci. 57: 305 - 324.

Ioannou, A. and A. Dimirkou, 1997. Phosphate adsorption on hematite, kaolinite, and kaolinite-hematite (k-h) systems as described by a constant capacitance model. J. Coll. Interface Sci. 192: $119-128$

IRMM, 2001. Institute of Reference Materials and Measurements: BCR-684 Certificate of Measurement; European Commission Community Bureau of Reference, Brussels.

Jaun, L., D. Finger, M. Zeh, M. Schurter and A. Wüest, 2007. Effects of upstream hydropower operation and oligotrophication on the light regime of a turbid peri-alpine lake. Aquat. Sci. 69: doi 10.1007/s00027-007-0876-3.

Maerki, M., B. Müller and B. Wehrli, 2006. Microscale mineralization pathways in surface sediments - a chemical sensor study in Lake Baikal. Limnol. Oceanogr. 51: 1342 - 1354.

Mieleitner, J. and P. Reichert, 2006. Analysis of the transferability of a biogeochemical lake model to lakes of different trophic state. Ecol. Modelling 194: 49 - 61 .

Moosmann, L., R. Gächter, B. Müller and A. Wüest, 2006. Is phosphorus retention in autochthonous lake sediments controlled by oxygen or phosphorus? Limnol. Oceanogr. 51: 763 771.

Müller, B., M. Maerki, C. Dinkel, R. Stierli and B. Wehrli, 2002. In situ measurements in lake sediments using ion-selective electrodes with a profiling lander system, p. 126-143. In M. Taillefert and T. F. Rozan (eds.), ACS Symposium Series. American Chemical Society.

Müller, B. and L. Sigg, 1990. Interaction of trace-metals with natural particle surfaces - comparison between adsorption experiments and field measurements. Aquatic Sci. 52: 75 - 92.

Müller, B. and L. Sigg 1992. Adsorption of lead(II) on the goethite surface - Voltammetric evaluation of surface complexation parameters. J. Coll. Interface Sci. 148: 517 - 532.

Müller, B., R. Stierli and A. Wüest, 2006a. Phosphate adsorption by mineral weathering particles in oligotrophic waters of high particle content. Water Resources Res. 42: W10414, doi: 10.1029/2005WR004778.

Müller, B., Y. Wang, M. Dittrich and B. Wehrli, 2003. Influence of organic carbon decomposition on calcite dissolution in surficial sediments of a freshwater lake. Water Res. 37: 4524 - 4532.

Müller, B., Y. Wang and B. Wehrli 2006b. Cycling of calcite in hard water lakes of different trophic states. Limnol. Oceanogr. 51: $1678-1688$.

Müller, R., M. Breitenstein, M. Mbuenemo Bia, C. Rellstab and A. Kirchhofer, 2007b. Bottom-up control of whitefish populations in ultra-oligotrophic Lake Brienz. Aquat. Sci. 69: doi 10.1007/ s00027-007-0874-5.

Obolkina, L. A., 2006. Planktonic ciliates of Lake Baikal. Hydrobiologia 568: 193 - 199.

Prasuhn, V., 2005. GIS-gestützte Abschätzung der Phosphoreinträge aus diffusen Quellen in die Gewässer im Einzug des Brienzersees, Internal report, Agroscope FAL, Reckenholz, http://www.eawag.ch/brienzersee. 
Prasuhn, V. and R. Mohni, 2003. GIS-gestützte Abschätzung der Phosphor- und Stickstoffeinträge aus diffusen Quellen in die Gewässer des Kantons Bern, Internal report. Eidg. Forschungsanstalt für Agrarökologie und Landbau, Zürich-Reckenholz, http://www.eawag.ch/brienzersee.

Rellstab, C., V. Maurer, M. Zeh, H. R. Bürgi and P. Spaak, 2007. Temporary collapse of the Daphnia population in turbid and ultra-oligotrophic Lake Brienz. Aquat. Sci. 69: doi 10.1007/ s00027-007-0872-7.

Ruban, V., J. Lopez-Sanches, P. Pardo, G. Rauret, H. Muntau and P. Quevauiller, 1999. Selection and evaluation of sequential extraction procedures for the determination of phosphorus forms in lake sediment. J. Environm. Monit. 1: 51 - 56 .

Ruban, V., J. Lopez-Sanches, P. Pardo, G. Rauret, H. Muntau and P. Quevauiller, 2001. Harmonized protocol and certified reference material for the determination of extractable contents of phosphorus in freshwater sediments - A synthesis of recent works. Fresenius J. Anal. Chem. 370: 224 - 228.
Sinaj, S., F. Mächler, E. Frossard, C. Faisse, A. Oberson and C. Morel, 1998. Interference of colloidal particles in the determination of orthophosphate concentrations in soil water extracts. Commun. in soil sci. plant anal. 29: $1091-1105$.

Stumm, W. and J. J. Morgan, 1996. Aquatic Chemistry, 3rd ed., Wiley Interscience, New York, 1022 pp.

Wan, G. J., P. H. Santschi, M. Sturm, K. Farrenkothen, A. Lueck, E. Werth and Ch. Schuler, 1987. Natural $\left({ }^{210} \mathrm{~Pb},{ }^{7} \mathrm{Be}\right)$ and fallout $\left({ }^{137} \mathrm{Cs},{ }^{239,240} \mathrm{Pu},{ }^{90} \mathrm{Sr}\right)$ radionuclides as geochemical tracers of sedimentation in Greifensee, Switzerland. Chem. Geol. 63: $181-196$.

Weiss, R. F., E. C. Carmack and V. M. Koropalov, 1991. Deep-water renewal and biological production in Lake Baikal. Nature 349: $665-669$.

Wüest, A., M. Zeh and J. D. Ackerman, 2007. Preface: Lake Brienz Project: An interdisciplinary catchment-to-lake study. Aquat. Sci. 69: doi 10.1007/s00027-007-0016-0.

\section{To access this journal online: http://www.birkhauser.ch/AS}

